hydrogen as would unite with oxygen in the formation of water; and this is the theory contained in most modern text-books on combustion prepared for the use of English-speaking students, and generally employed in calculations by the scientific men of England and the United States.

About the year 1860, Messrs. Scheurer-Kestner and MeunierDollfus made experiments on the heat evolved by the combustion of various coals; using the same method as that employed by Messrs. Favre and Silbermann, and checking the latter's experiments on wood charcoal and hydrogen gas, before testing the coals. The experiments on coals showed that it was incorrect to calculate the heat of combustion of coal from the heat of its combustible constituents as determined by Favre and Silbermann; or, in other words, that it was not correct to assume that the carbon in coal was of the same density as wood charcoal, and that the hydrogen of the coal was in a gaseous state: these being the necessary assumptions, when Messrs. Favre and Silbermann's constants are used in the formula to which reference has been made above. The report of Messrs. Scheurer-Kestner and Meunier-Dollfus has been well named 'classical,' - all operations and calculations being fully detailed, - so that, speaking rationally or scientifically, the conclusion seems inevitable that a scientific investigator must either find some error or accept the results. Well, how has the scientific world, that is to say, the English-speaking scientific world, received these results? Generally by ignoring them, and going on in the good old way, according to the creed formulated by Messrs. Favre and Silbermann. Here is a scientific (?) statement made by one investigator who has carefully studied the report (Mr. B. F. Isherwood, in Journal of the Franklin Institute, July, I884):-

"The results of the calorimetrical experiments made by ScheurerKestner and Meunier-Dollfus on the heat of combustion of the Alsatian coals, were never accepted by the British scientists, notwithstanding that no error was ever pointed out in either the apparatus or the method employed. Nor could the writer ever accept them, although he bestowed the closest scrutiny and study upon them."

This is science, with a vengeance! "I can't find any mistakes in the methods or calculations," says the scientist, " but the results are opposed to my present belief, and I can't accept them. I have published numerous treatises containing calculations founded on the methods and clata of Favre and Silbermann, and these new results, which would condemn my work, must be ignored or denied." 1

The statement contained in the above quotation, that the results of the experiments made by Messrs. Scheurer-Kestner and MeunierDollfus were never accepted by the British scientists, is not absolutely correct. Mr. John Percy, in the last edition of his treatise on fuel, gives the results, and calls attention to the inaccuracy of the ordinary method of calculation. Similar corrections are made in the last supplement of Watt's 'Dictionary of Chemistry.'

Quite recently, Messrs. Scheurer-Kestner and Meunier-Dollfus have repeated their former experiments, obtaining substantially the same results as before; and it seems probable that right methods of calculating the heat of combustion of coal will be generally adopted before long. If the results are true, they will certainly be accepted, some day; but the length of time during which they have patiently awaited admission to the temple inhabited by English-speaking scientists is a sufficient answer to the question, 'If a new fact, overturning some established theory, is presented, do the scientists examine it critically, and either disprove or accept it, or do they ignore it as long as they can, and only take it into their hearts when worn out by its persistent demands?' If a truth is announced, there need be no fear that it will not prevail in the end; but numerous facts, similar to that just cited, sufficiently disprove

1 Scientific men seem to hunt in couples, so to speak ; and Mr. Bonney, in answering the Duke of Argyll (Nature, Nov. 24), argues in the same manner as his American brother in the above quotation. He does not accept the new theory, and thinks that no reasons are required for his disbelief. Here are his words :-

"To conclude, the Duke still - and this is our special complaint - treats the matter rather according to ecclesiastical than to scientific method. He is fully permatter rather according to ecclesiastical than to scientific method. He is fully per-
suaded of the excellence of Mr. Ir Iurray's hypothesis, and considers it to be 'one of suaded of the excellence of Mr. Murray's hypothesis, and considers it to be 'one of
those discoveries in science which are self-luminous,' and 'must carry conviction to those discoveries in science which are self-luminous,' and ' must carry conviction to
all.' Very well, but there are some people, not very few in number, who do not share this opinion."

Hail to the new science, announced by Mr. Bonney! The voice of many people is the voice of God. the theory fondly entertained by many scientists, that they have reached the ideal state where they desire only to know the truth, regardless of consequences.

Another brilliant French writer, Mr. Alexander Dumas, well sums. up the matter, as follows :-

"Il est vrai que peut-être les contemporains ne me croiront pas. ... Qu'importe! je l'aurais dit; d'autres me croiront : la vérité est une de ces, étoiles qui peuvent rester des mois, des années, des. siècles, dans les profondeurs du ciel, mais qui finissent toujours par être découvertes un jour ou l'autre. J'aime mieux être le fou qui se voue à la recherche de ces étoiles-là, que le sage qui salue et qui. adore, les uns après les autres, tous ces soleils que nous avons vus se lever, que l'on nous a donnés pour des astres immutables, et qui, à tout prendre, n'ont jamais été que des météores plus ou moins. durables, plus ou moins brilliants, plus ou moins trompeurs, toujours fatals!" RICHARD H. BUEL.

New York, Dec. 7 .

\section{The 'Act of God' and 'Fuerza Mayor.'}

Mr. Appleton Morgan's 'Act of God' and Mr. Nevin's 'fuerza mayor' appear to me to be pretty much alike, and to, threaten a new peril to railway travel, - a peril, according to $\mathrm{Mr}_{\text {. }}$ Nevin, which in Mexico is already to be encountered. I tremble to think what might happen, for example, if the engineer of the locomotive should happen to sneeze just as he passed a signal that a bridge had been carried away somewhere on the Mexican Central Railroad by " the flooding of a river." Here would be a double'fuerza mayor ;' for an inclination to sneeze is certainly irresistible, and, besides, "the flooding of a river" certainly relieved from the responsibility for the irresistible inclination, even if, according to Mr. Nevin, it did not relieve the watchman from the duty of putting up the danger-signal. But, although we may have to take our lives in our hands when we travel by rail in Mexico (according to Mr. Nevin), I hope that time has not yet come in the United States.

In short, this is the actual practical answwer to Mr. Morgan's cleverly reasoned and delightfully insouciant paper. It may not be the answer a railway lawyer would write, or would recognize as sufficient, but, from the travelling public's standpoint, it is all there is to be said. It is all very well for the sleek attorneys of great railroad corporations to say that so long as the company provides, as Mr. Morgan says, "the last improvement in safety-insuring devices," its responsibility for the safety of those it transports ceases. "Let us bow to the Divine Will, gentlemen of the jury," says Mr. Morgan. "An overruling Providence has decreed that my client should "roast thirty-two human beings in slow agony on a floor of ice at White River. But our track was in perfect order, our engine was all right, we were running on time. We are not legally to blame." Would Mr. Appleton Morgan have bowed to the Divine Will if he had happened to have been rescued in a half-roasted condition at White River, less an arm, or an eye, or a leg? I venture to say he would have done nothing of the sort. I venture to say he would have commenced proceedings against the company for twenty-five thousand or fifty thousand dollars as soon as he could swear to a complaint. And yet Mr. Morgan will concede that the accident at White River could not have happened in spite of the Divine Will.

The people of this nation do not exist at the will and pleasure of the railway-companies; nor is this nation governed by Mexican laws. Mr. Morgan's familiarity with his subject enables him to write very plausibly concerning the rights and duties of railwaycompanies; but he cannot convince me, for one, that they are not more sinning than sinned against. If the principle of the 'Act of God ' is to be resurrected in the United States, as in Mexico, where is the line to be drawn, and who is to draw it, - the railway-companies, or their ingenious lawyers? GEORGE BRADWIN.

Jersey City, Dec. 6.

\section{The Flight of Birds.}

My friend, Prof. Frank H. Storer, has called my attention to an important note on the wings of birds, by that accurate and indefatigable investigator, Prof. Jeffries Wyman. It is to be found on p. 169, vol. v., Proceedings of the Boston Natural History Society. This note is all too short, but forms an interesting adjunct to the 